\title{
Cost and Time Management Efficiency Assessment for Large Road Projects Using Data Envelopment Analysis
}

\author{
Changiz AHBAB ${ }^{1}$ \\ Sahand DANESHVAR ${ }^{2}$ \\ Tahir ÇELIK ${ }^{3}$
}

\begin{abstract}
Upon the completion of national road projects, their cost and time deviations are often reported. These deviations from the projected values are a result of complications in the time and cost management of such projects. Controlling the cost and time overrun of projects is important for successful implementation and efficient project management. However, few studies have attempted to measure the project cost and time management efficiency in civil engineering. Thus, this issue requires further investigation. In this study, large road projects that had poor cost and time management were selected. The chosen projects were configured as Decision Making Units (DMUs) in a Data Envelopment Analysis (DEA). It is a nonparametric modern mathematical tool for measuring relative managerial performance and determining efficient DMUs. The cost and time management efficiency of the projects was calculated using this tool, and the resulting values were ordered according to importance. The identified results demonstrate that additional works, inaccurate initial project scope, increase or change in the scope of the project, and design changes are four common critical causes that strongly impact both time and cost management efficiency.
\end{abstract}

Keywords: Data envelopment analysis, management performance evaluation, project management efficiency, project management, cost and time overrun.

\section{INTRODUCTION}

Cost and time overruns are common phenomena in large civil engineering projects. These variables are defined as discrepancies between predicted cost and duration with actual total cost, and time taken at project completion. Exceeding the budget and running over the

\section{Note:}

- This paper has been received on January 08, 2018 and accepted for publication by the Editorial Board on November 12, 2018.

- Discussions on this paper will be accepted by May 31, 2019.

- https://dx.doi.org/10.18400/tekderg.375664

1 Eastern Mediterranean University, Department of Civil Engineering, Famagusta, Northern Cyprus changiz.ahbab@emu.edu.tr - https://orcid.org/0000-0002-0780-1375

2 Eastern Mediterranean University, Department of Industrial Engineering, Famagusta, Northern Cyprus sahand.daneshvar@emu.edu.tr - https://orcid.org/0000-0002-8597-3463

3 Cyprus International University, Department of Civil Engineering, Nicosia, Northern Cyprus tcelik@ciu.edu.tr - https://orcid.org/0000-0002-2943-0640 
schedule for the implementation of projects is a significant problem. This has encouraged researchers to conduct detailed studies on the causes that impact the contracted cost and schedule.

Arditi et al. [1] investigated the sources of cost overrun in public projects. In the first statistical treatment of the problem, Flyvbjerg et al. [2] studied the frequency and magnitude of cost overrun in transport infrastructure projects. They concluded that transport infrastructure projects generally exceed their time and/or cost, and also identified the cost as a highly uncertain criteria. They also found that $90 \%$ of transportation infrastructure projects experience cost escalation, indicating that cost overrun is a pervasive phenomenon. Assaf and Al-Hejji [3] studied the sources of extensions in the duration of large construction projects and identified the causes leading to delay. It was found that approximately $2 / 3$ of large projects experience different degree of time overruns. In other studies, the cost overrun causes impacting projects were identified and categorized [4]. Ahsan and Gunawan [5] inspected and analysed the cost and time variation of 100 international development projects. They identified the major causes of time extension and cost overrun. Ahbab and Celik [6] proved the existence of time and cost overrun by obtaining the critical causes affecting time and cost criteria in large road projects. Cheng [7] studied the important causes impacting on the cost of a project, and developed new methods to control and avoid cost overrun. The aim of these investigations is to assist project managers by highlighting critical causes and directing their efforts to complete the project successfully $[8,9,10,11]$.

There are different criteria for benchmarking a completed project as successful. The parties involved in a project (Investor, client, contractor, consultant, and end-consumer) may assess the outcome differently. For instance, the success of a project was traditionally compared to the output and interrelation of time, cost, and quality through the Barnes' Iron Triangle [12].

Empirical and academic research has revealed that project managers play a vital role in delivering projects within the specified timeframe, and budget of the contract. This starring role in large projects is of high importance. Olsen [13] defined successful project management as the delivery of a project within the time, cost, and quality constraints. Munns and Bjeirmi [14] noted the importance of good project management leading to a higher possibility of project success. It is obvious that the extent to which the project manager controls the budget and schedule will affect the probability of success. The importance of applying project management, and project management methods has been widely researched by Besner and Hobbs [15], Chou and Yang [16], de Carvalho et al. [17], and Joslin and Muller [18]. Based on these studies, it can be concluded that the role of efficient project management is particularly important.

Efficiency can be defined as the extent of the deviation between actual performance and anticipated performance, and should be compared with an objective function [19]. Investing in building organizational project management expertise will lead to greater efficiencies in projects [20].

Serrador and Turner [21] have demonstrated that project efficiency and project success correlates moderately strongly with the overall project success. Project management efficiency can be characterized as utilization of effective project administration techniques to accomplish the clearly defined project scope and goals with minimum possible deviation. 
Iyer and Banerjee [22] measured and ranked managerial efficiency in terms of the schedule during project execution.

Investors and project owners are attentive to ensuring a successful project through efficient project management, mostly in terms of time and budget variables. Project Management Efficiency can be affected by different causes, leading to cost deviations and delays in the project.

It is believed that there is a vital need for greater focus on extracting the causes that critically reduce the efficiency of project managers. To achieve this goal and obtain reliable results, mathematical methods can be applied to compute management efficiency or make a comparison between project management efficiencies.

The comparison of projects in terms of management efficiency can be undertaken by different parametric and nonparametric methods. Nonparametric methods do not consider the studied data as following a certain distribution, and place no (or very restricted) assumptions on the data. Nonparametric methods are mostly used for nominal or ordinal datasets, whereas parametric methods are applied to data sets with interval or ratio scales [23].

Common nonparametric techniques are Data Envelopment Analysis and Free Disposable Hull analysis. The Distribution-Free Approach, Stochastic Frontier Approach, and Thick Frontier Approach are parametric methods for efficiency measurement [24].

Data Envelopment Analysis is a powerful tool and is extensively used because of its advantages in determining efficiency, such as the ability to handle multiple inputs and outputs in a model, no assumptions about the input weights, and the ability to relate the resources expended on a certain activity to the level of success for that particular action [25] and [26].

Thus, due to advantages of this tool as an effective mathematical model for determining project efficiencies, authors consider it feasible and reasonable to apply this technique. Another incentive for using this tool is the ability to compare project management efficiencies based on the multiple defects influencing the time and cost criteria. To the best knowledge of the authors, this is the first time that Data Envelopment Analysis has been applied to large transportation projects to assist decision makers in efficient project management.

In this study, 63 large transportation projects with cost and time deviations were selected from the projects sponsored and financed by the Asian Development Bank. The selected projects are large in terms of cost criteria, with estimated total cost in between 12 and 1566 million dollar. Through project completion reports, Bank evaluates and rates the success of its projects according to relevance, effectiveness, efficiency, and sustainability [27]. On average, each report is about 60 pages and contains the project description, evaluation of the bank in design and execution of the project, performance, and overall assessment and recommendations at the end. Detailed Information about outputs of the project including scope and objectives, authorized and actual costs detected responsible causes for overruns, disbursements, schedule and extension causes, and implementation arrangements are also provided.

The identified causes of time and cost overruns were extracted from project completion reports and sorted in terms of the number of replications. Then, using Data Envelopment Analysis as a robust tool, the relative efficiency scores of project management for the selected 
projects were computed and sorted accordingly. Using this methodology, the causes that negatively impacted the efficiency of project management and led to unsuccessful project status were recognized and extracted. These causes should be considered and addressed by policy and decision makers as critical negative efficiency causes. Additionally, more attention to these causes will help to improve the project management efficiency, and increase the likelihood of project success.

The first objective of this paper is to compute and compare the time and cost management efficiency of projects (Decision making units) regarding their contributing causes using Data Envelopment Analysis. Then, the importance of causes that adversely affect the management efficiency in terms of time and cost is quantified by applying sensitivity analysis. In this way, policy and decision makers in Asian Development Bank, government transportation departments, contract affairs units, project managers, and contractor companies will be able to improve their management efficiency. It is believed that the developed analytical tool can be used to benchmark the managerial efficiency through mitigation of the seriously continuing problems of time delays and cost overruns and objectively recognize management efficiency gaps. The rest of article is organized as follows. First, Data Envelopment Analysis methodology is illustrated. Second, Data aggregation, selection and preparation is described. Then, achieved results are discussed. As a final point, conclusions are provided.

\section{DATA ENVELOPMENT ANALYSIS}

Data Envelopment Analysis (DEA) is a powerful service management and benchmarking technique developed by Charnes, Cooper, and Rhodes (CCR) in 1978 to evaluate non-profit, and public-sector organizations [28]. Since its inception, this method has been used to identify ways of improving services that are not visible using other techniques. It is an evaluation tool for a set of entities called decision making units (DMUs) with multiple inputs and multiple outputs. It is also a decision-making tool that measures the relative efficiency of comparable units. The CCR model is the first and most fundamental DEA model to evaluate the relative efficiency of DMUs.

Consider a set of homogenous DMUs as $D M U_{j}(j=1, \ldots, n)$. Each DMU consumes $m$ inputs to produce $r$ outputs. Suppose that $X_{j}=\left(x_{1 j}, \ldots, x_{m j}\right)$ and $Y_{j}=\left(y_{1 j}, \ldots, y_{r j}\right)$ are vectors of input and output values for $D M U_{j}$, respectively, and let $X_{j} \geq 0$ and $Y_{j} \geq 0, Y_{j} \neq 0$. The

Production Possibility Set (PPS) $T_{C}$ can be constructed by considering the following postulates.

The observed activities $\left(X_{j}, Y_{j}\right) \quad j=1,2, \ldots n$ belong to $T_{C}$;

If an activity $(X, Y)$ belongs to $T_{C}$, then activity $(t X, t Y)$ belongs to $T_{C}$ for any positive scalar $t$. This property is called the constant returns-to-scale assumption;

For any activity $(X, Y)$ in $T_{C}$, any semi-positive activity $(\bar{X}, \bar{Y})$ with $\bar{X} \geq X$ and $\bar{Y} \leq Y$ is included in $T_{C}$;

Any convex combination of activities in $T_{C}$ belongs to $T_{C}$; 
$T_{C}$ is the smallest set that satisfies the above four properties.

With respect to the above assumptions, $T_{C}$ can be defined as follows:

$T_{C}=\left\{(X, Y) \mid X \geq \sum_{j=1}^{n} \lambda_{j} X_{j}, Y \leq \sum_{j=1}^{n} \lambda_{j} Y_{j}, \lambda_{j} \geq 0, \forall j\right\}$

Now, for the evaluation of DMUs, $D M U_{o}$ with $\left(X_{0}, Y_{0}\right)$ as the input-output vector is written from an input orientation with some free value $\theta$ such that $\left(\theta X_{0}, Y_{0}\right)$ belongs to PPS. Thus,

$\operatorname{Min} \theta$

S.t $\left(\theta X_{0}, Y_{0}\right) \in T_{C}$

Based on the definition of $T_{C}$, the following linear programming problem is obtained:

$$
\begin{array}{ll}
\text { Min } & \theta \\
\text { S.t } & -\sum_{j=1}^{n} \lambda_{j} X_{j}+\theta X_{0} \geq 0 \\
& \sum_{j=1}^{n} \lambda_{j} Y_{j} \geq Y_{0} \\
& \lambda_{j} \geq 0, j=1, \ldots, n . \\
& \theta \text { free }
\end{array}
$$

The dual of the above linear programming problem is used to obtain values for the input weights $v_{i}$ and the output weights $u_{r}$ :

$$
\begin{array}{ll}
\text { Max } & \theta=\sum_{r=1}^{s} u_{r} y_{r o} \\
\text { s.t } \quad & \sum_{i=1}^{m} v_{i} x_{i o}=1 \\
& \sum_{r=1}^{s} u_{r} y_{r j}-\sum_{i=1}^{m} v_{i} x_{i j} \leq 0 \quad j=1,2, \ldots, n \\
& v_{i} \geq 0 \quad i=1,2, \ldots, m \\
& u_{r} \geq 0 \quad i=1,2, \ldots, s
\end{array}
$$

In vector format, this can be written as follows:

$$
\begin{array}{ll}
\text { Max } & \theta=U Y_{o} \\
\text { s.t } & V X_{o}=1 \\
& U Y_{j}-V X_{j} \leq 0 \quad j=1,2, \ldots, n \\
& U \geq 0 \\
& V \geq 0
\end{array}
$$


$D M U_{o}$ is said to be CCR-efficient if $\theta^{*}=1$ and there exists at least one optimal $\left(V^{*}, U^{*}\right)$ with $V^{*}>0$ and $U^{*}>0$. DMU $U_{o}$ is said to be CCR-weak efficient if $\theta^{*}=1$ and there exists $V^{*} \geq 0$ and $U^{*} \geq 0$ where at least one of $V^{*}$ or $U^{*}$ is equal to zero. Otherwise, $D M U_{o}$ is CCR-inefficient, that is, $\theta^{*} \neq 1$.

Clearly, the optimal solution for both (3) and (4) is the same, which shows the efficiency value of the evaluation of $D M U_{o}\left(X_{0}, Y_{0}\right)$. The optimal solutions of these models give us other useful information about $D M U_{o}$.

Assume that $D M U_{o}\left(X_{0}, Y_{0}\right)$ is evaluated by model (3) and $\lambda^{*}=\left(\lambda_{i}^{*}, \ldots, \lambda_{j}^{*}, \ldots \lambda_{n}^{*}\right)$ with an objective function value of $\theta^{*}$ as its optimal solution. In vector $\lambda^{*}, \lambda_{j}^{*}>0$ shows the effect of $D M U_{j}$ in $\theta^{*}$ toward the efficiency value of $D M U_{o}$. Then, $D M U_{j}$ can be considered as a benchmark in the efficiency improvement process of $D M U_{o}$. Alternatively, if it is assumed that $\left(U^{*}, V^{*}\right)$ with an objective function of $\theta^{*}$ is the optimal solution of model (4) for $D M U_{o}$ $\left(X_{0}, Y_{0}\right), u_{r}^{*}(r=1, \ldots, s)$ and $v_{i}^{*}(i=1, \ldots, m)$ can be considered as the weight or degree of importance of the $r^{\text {th }}$ output and $i^{\text {th }}$ input, respectively, in the efficiency value. Similarly, models based on variable returns-to-scale [29] may be used for this purpose.

Obviously, if $u_{r}^{*}$ or $v_{i}^{*}$ are equal to zero, the associated output or input has no effect on the efficiency of $D M U_{o}$ [30].

One of the proposed methods for understanding the importance of inputs and outputs in the DMU efficiency values is to compute the average of the optimal weight values for $u_{r}^{*}$ and $v_{i}^{*}$ and compare these average values. Another significant method for the sensitivity analysis is to eliminate the inputs and outputs one by one, and compute the efficiency of the DMUs with the remaining inputs and outputs. Any decrement in the average efficiency value of a DMU shows the degree of importance of the eliminated input or output [31].

Furthermore, the sensitivity analysis for individual efficient DMUs may be employed to retain their efficiency against small changes in input or output values [32].

In this study, constant returns-to-scale are assumed for the evaluation of the observed DMUs. This is because the inherent nature of the construction industry means that increasing the number of contributing causes will increase the potential cost and time overrun.

\section{DATA AGGREGATION, SELECTION, AND PREPARATION}

International organizations and government departments routinely collect records and provide reports about national and international projects. The World Bank, Asian Development Bank, and the US Department of Transportation are among several organizations that frequently publish project data. Sometimes, researchers use the published data as secondary data. The advantages over primary data include the reduced time and expense of obtaining the data, the higher quality of the data, and the enhanced objectivity, accuracy, validity, and reliability of the data [33].

In this research, the Project Completion Reports published by Asian Development Bank were used as secondary data. Afterward 63 projects that suffered time and/or cost overruns were 
selected (See Appendix2). Quantity of time and cost deviations in percentage from authorized duration and budget reported in each document were carefully computed and obtained. In the next step of this research, the documents were carefully scanned to find the causes that had adverse effects on time and cost criteria in the projects. As a result, 66 causes were identified as having an adverse influence leading to either time or cost overrun. To identify the most significant causes for each criterion, the number of repetitions of each cause was counted and sorted. Tables 1 and 2 list the affecting causes that were repeated 10 times or more within the projects. (See Appendix 1 for full list of adverse time and cost causes and their number of replications.)

Table 1 - Ranking of the first twenty critical causes influencing the time of the project

\begin{tabular}{|c|c|c|c|}
\hline Code & Causes of Delay & $\begin{array}{c}\text { No. } \\
\text { Repetition }\end{array}$ & Rank \\
\hline 19 & Long period between time of bidding and contract award & 16 & 1 \\
\hline 33 & Delay in mobilization by contractor & 13 & 2 \\
\hline 43 & $\begin{array}{l}\text { Severe weather problems (heat, cold, snow, rain, } \\
\text { cyclone) }\end{array}$ & 12 & 3 \\
\hline 58 & Poor procurement procedure & 11 & 4 \\
\hline 21 & Design changes & 10 & 5 \\
\hline 31 & Poor performance of contractor & 10 & 5 \\
\hline 14 & Slowness of the owner's decision-making process & 10 & 5 \\
\hline 20 & Increase in quantity of work (Additional works) & 9 & 6 \\
\hline 7 & $\begin{array}{l}\text { Poor project management, construction management and } \\
\text { supervision }\end{array}$ & 8 & 7 \\
\hline 52 & Increase or change in scope of the Project & 8 & 7 \\
\hline 63 & Delay in Land Acquisition & 8 & 7 \\
\hline 35 & $\begin{array}{l}\text { Slow or Delayed material or equipment delivery to } \\
\text { project site }\end{array}$ & 7 & 8 \\
\hline 2 & Inaccurate initial project scope and cost estimate & 7 & 8 \\
\hline 64 & Delay in appointment of consultant & 7 & 8 \\
\hline 17 & $\begin{array}{l}\text { Delay in Approval of feasibility study, drawings and } \\
\text { material }\end{array}$ & 6 & 9 \\
\hline 50 & $\begin{array}{l}\text { Complicated administrative and governmental } \\
\text { procedures (institutional problems) }\end{array}$ & 6 & 9 \\
\hline 18 & Financial difficulties of owner/Client & 5 & 10 \\
\hline 44 & Political issues-Changes & 5 & 10 \\
\hline 42 & $\begin{array}{l}\text { Poor and unforeseen site conditions ( Location, ground, } \\
\text { geological, events, security, ETC) }\end{array}$ & 5 & 10 \\
\hline 36 & $\begin{array}{l}\text { Unavailability or shortage of required materials in the } \\
\text { local market on time }\end{array}$ & 5 & 10 \\
\hline
\end{tabular}


In the next step, the data were prepared and modelled using the Performance Improvement Management software [34]. A total of 51 projects were input related to the 20 most frequent causes of time overruns and 38 projects with the 10 most frequent causes of cost overruns were also modelled. This combinations of selection was considered because the number of selected projects has to be higher than the maximum between $(\mathrm{m} \times \mathrm{s})$ and $[3 \times(\mathrm{m}+\mathrm{s})]$, being $\mathrm{m}$ and $\mathrm{s}$ the number of input and output criteria [35]. The output from each model was the inverse time and cost overrun percentage.

Table 2 - Ranking of the first ten critical causes influencing the cost of the project

\begin{tabular}{|c|l|c|c|}
\hline Code & \multicolumn{1}{|c|}{ Causes of Cost Overrun } & $\begin{array}{c}\text { No. } \\
\text { Repetition }\end{array}$ & Rank \\
\hline 37 & Fluctuation and escalation in prices & 21 & 1 \\
\hline 47 & Change in exchange rate & 13 & 2 \\
\hline 53 & Underestimated and inaccurate appraisal & 12 & 3 \\
\hline 52 & Increase or change in scope of the project & 11 & 4 \\
\hline 62 & $\begin{array}{l}\text { Increase in the amount of land acquisition, price, and } \\
\text { Compensation }\end{array}$ & 11 & 4 \\
\hline 21 & Design changes & 10 & 5 \\
\hline 2 & Inaccurate initial project scope and cost estimate & 7 & 6 \\
\hline 20 & Increase in quantity of work (Additional works) & 7 & 6 \\
\hline 42 & $\begin{array}{l}\text { Poor and unforeseen site conditions ( Location, ground, } \\
\text { geological, events, security) }\end{array}$ & 6 & 7 \\
\hline 61 & $\begin{array}{l}\text { Additional project management, consultancy and } \\
\text { administration costs }\end{array}$ & \multicolumn{1}{|c|}{6} \\
\hline
\end{tabular}

\section{RESULTS AND DISCUSSIONS}

The main purpose of this paper is to draw attention to the performance and managerial efficiency of large road projects in terms of time and cost criteria. Therefore, in this step, the project management efficiency of the projects was measured using the Performance Improvement Management software [34]. This was done by applying the CCR model considering the causes affecting each of the time and cost criteria. The relative managerial efficiency measurement is provided as an efficiency score by the software. The results are summarized in Tables 3 and 5 for time and cost, respectively.

Time and cost management efficiency can be defined as a set of management techniques which minimizes the overall effect of adverse causes leading to time and cost overrun. In other word, managing tasks by reducing the effect of adverse causes and reach to the best output, which is the completion of the project in specified time and budget. Managerial efficiency can be expressed as a relative measure. Different project management teams have different efficiency in taking decisions and controlling cost and time criteria in presence of 
affecting causes. Their ability in prioritizing the tasks, taking actions against causes and minimizing defects of causes will show the extent of their success in efficient time and cost management.

Table 3 - Managerial relative efficiency score for time criteria of 51 projects

\begin{tabular}{|c|c|c|c|c|c|c|c|}
\hline Project & $\begin{array}{c}\text { Efficiency } \\
\text { Score }\end{array}$ & Project & $\begin{array}{c}\text { Efficiency } \\
\text { Score }\end{array}$ & Project & $\begin{array}{c}\text { Efficiency } \\
\text { Score }\end{array}$ & Project & $\begin{array}{c}\text { Efficiency } \\
\text { Score }\end{array}$ \\
\hline 01 & 39.40 & 16 & 17.13 & 32 & 100 & 48 & 12.93 \\
\hline 02 & 100 & 18 & 16.13 & 33 & 100 & 49 & 98.39 \\
\hline 03 & 15.45 & 19 & 67.12 & 34 & 23.04 & 50 & 100 \\
\hline 04 & 100 & 20 & 16.90 & 35 & 100 & 51 & 100 \\
\hline 06 & 100 & 21 & 100 & 36 & 100 & 52 & 6.54 \\
\hline 07 & 100 & 22 & 100 & 37 & 100 & 53 & 30.93 \\
\hline 08 & 100 & 23 & 100 & 39 & 100 & 55 & 100 \\
\hline 09 & 6.83 & 24 & 60.37 & 41 & 14.55 & 56 & 100 \\
\hline 10 & 100 & 25 & 100 & 42 & 90.97 & 59 & 12.06 \\
\hline 12 & 60.65 & 26 & 15.81 & 43 & 100 & 61 & 14.70 \\
\hline 13 & 36.30 & 29 & 100 & 44 & 100 & 62 & 100 \\
\hline 14 & 100 & 30 & 4.15 & 46 & 6.09 & 63 & 36.17 \\
\hline 15 & 100 & 31 & 50.60 & 47 & 100 & & \\
\hline
\end{tabular}

As can be seen in Table 3, the relative managerial efficiency in terms of time for 27 out of 51 projects is $100 \%$. This can be interpreted as follows:

1) Despite presenting various difficulties and delays, the different parties involved in the management of these projects succeeded in accomplishing the project efficiently. For instance, project 29 partially and efficiently overcame seven causes that affected the project time. Those causes were the long-time gap between project preparation and real start date of construction, the lack of knowledge in regional owners and local contractors with the circumstances of the Fédération International des Ingénieurs-Conseils (FIDIC), delays in the approval of some changes by the owner, the unavailability or shortage of required materials in the local market, equipment and manpower shortages, unforeseen events, and a tsunami. Those unexpected issues resulted in a time overrun of only 15\% (See Appendix 2).

2) In project 49 , the relative efficiency score in time management is $98.39 \%$. Project managers faced with only two causes in this project including unforeseen events and the unavailability or shortage of required materials in the local market which are in common with project 29. This project was accomplished with $33 \%$ of time overrun (See Appendix 2).

This evidence shows that the project managers of this project could not able to efficiently overcome the common causes in compare with other project which overcome more causes with less time overrun. 
In the second step, the focus was on the causes that critically influenced and impacted the managerial efficiency. Therefore, projects with less than $100 \%$ efficiency were investigated. A table was prepared based on the number of repetitions of causes in the selected inefficient projects. The causes were then sorted and those having the most critical effect on time criteria, leading to inefficient project management, are presented in Table 4.

Table 4. Number of repetitions of causes influencing time management efficiency in the inefficient projects

\begin{tabular}{|c|c|c|c|c|c|c|c|c|c|c|c|c|c|c|c|c|}
\hline Code* & 33 & 21 & 7 & 43 & 31 & 19 & 14 & 58 & 2 & 52 & 17 & 35 & 18 & 20 & 23 & 63 \\
\hline 01 & & & & & & & $\mathrm{x}$ & $\mathrm{x}$ & & & & & & & & \\
\hline 03 & & $\mathrm{x}$ & & & $\mathrm{x}$ & & & & $\mathrm{x}$ & & & & $x$ & & & \\
\hline 09 & & $\mathrm{x}$ & & & & $\mathrm{x}$ & & $\mathrm{x}$ & & $\mathrm{x}$ & $\mathrm{x}$ & & & & & $\mathrm{x}$ \\
\hline 12 & & & & & & $\mathrm{x}$ & & $\mathrm{x}$ & & & & & & & & \\
\hline 13 & & $\mathrm{x}$ & $\mathrm{x}$ & & $\mathrm{x}$ & & & & & & & & & & & $\mathrm{x}$ \\
\hline 16 & & & & & & $\mathrm{x}$ & & $\mathrm{x}$ & $\mathrm{x}$ & $\mathrm{x}$ & & & & $\mathrm{x}$ & & $\mathrm{x}$ \\
\hline 18 & $\mathrm{x}$ & & & $\mathrm{x}$ & & & & & $\mathrm{x}$ & $\mathrm{x}$ & & $\mathrm{x}$ & & & & \\
\hline 19 & & & & & & & & & & & & & & & & \\
\hline 20 & 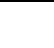 & & $\mathrm{x}$ & $\mathrm{x}$ & $\mathrm{x}$ & & & & - & 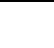 & & & $\mathrm{x}$ & & & \\
\hline 24 & & & & & & & & & $\mathrm{x}$ & $\mathrm{x}$ & & & $\mathrm{x}$ & $\mathrm{x}$ & & \\
\hline 26 & $\mathrm{x}$ & $\mathrm{x}$ & & $\mathrm{x}$ & & & & & & & & & $\mathrm{x}$ & $x$ & & $\mathrm{x}$ \\
\hline 30 & $\mathrm{x}$ & $\mathrm{x}$ & $\mathrm{x}$ & & $\mathrm{x}$ & & & & & & & & & & & \\
\hline 31 & $\mathrm{x}$ & & & & $\mathrm{x}$ & $\mathrm{x}$ & $\mathrm{x}$ & & & & $\mathrm{x}$ & & & & $\mathrm{x}$ & \\
\hline 34 & & & $\mathrm{x}$ & $\mathrm{x}$ & $\mathrm{x}$ & & $\mathrm{x}$ & & & & $\mathrm{x}$ & & & & & \\
\hline 41 & $\mathrm{x}$ & & $\mathrm{x}$ & & & & $\mathrm{x}$ & $\mathrm{x}$ & & & & & & & $x$ & \\
\hline 42 & & & & & & & $\mathrm{x}$ & & & & & $\mathrm{x}$ & & & & \\
\hline 46 & & $\mathrm{x}$ & $\mathrm{x}$ & & & & & & & & & $\mathrm{x}$ & & & & \\
\hline 48 & $\mathrm{x}$ & $\mathrm{x}$ & & & & $\mathrm{x}$ & & $\mathrm{x}$ & & & $\mathrm{x}$ & & & & $\mathrm{x}$ & \\
\hline 49 & & & & & & & & & & & & & & & & \\
\hline 52 & $\mathrm{x}$ & $\mathrm{x}$ & $\mathrm{x}$ & $\mathrm{x}$ & & $\mathrm{x}$ & & & & & & $\mathrm{x}$ & & $\mathrm{x}$ & $\mathrm{x}$ & \\
\hline 53 & $\mathrm{x}$ & & & & & & & & & & & & & & & \\
\hline 59 & $\mathrm{x}$ & $\mathrm{x}$ & & $\mathrm{x}$ & & & & & & $\mathrm{x}$ & & & & & & \\
\hline 61 & & & & $\mathrm{x}$ & & & $\mathrm{x}$ & & & & & & & & & \\
\hline 63 & $\mathrm{x}$ & & & & & & & & $\mathrm{x}$ & & & & & & & \\
\hline Repetition & 10 & 9 & 7 & 7 & 6 & 6 & 6 & 6 & 5 & 5 & 4 & 4 & 4 & 4 & 4 & 4 \\
\hline$*$ & \multicolumn{16}{|c|}{ Refer to Appendix 1} \\
\hline
\end{tabular}


Based on Table 4, it can be concluded that delays in mobilization by the contractor, project design changes, and poor project management and supervision are the three main causes that severely affect the time management of projects.

Simultaneously, the efficiency of cost management was also studied, and Table 5 summarizes the managerial cost efficiency score for the investigated projects. This table clearly implies that 11 of the 38 projects are efficient in terms of cost management criteria. It clarifies that project managers could able to accomplish those 11 projects with efficient cost management despite presence of adverse causes that impacts the authorized cost. The other 27 project managers could not fully succeed in managing the cost against causes efficiently in comparing with successful project managers. For example, the US\$ 465 million project represented by project 36 is an efficient project. The different parties responsible for the management of this project dealt with inaccurate cost estimates in appraisal, changes in the scope of the project, changes in land acquisition prices, and design changes to complete the project with a cost overrun of just $2.2 \%$. Meanwhile project 37 was affected by three causes which are common with project 36 . Effect of causes and inefficient cost management led this project to $75 \%$ of cost overrun from $\$ 762$ million to $\$ 1,333$ million. In this point, in line with the reasons in time management efficiency part, the importance of efficient cost management is concluded. However, 27 out of the 38 projects investigated are inefficient projects.

Table 5 - Managerial relative efficiency score for cost criteria of 38 projects

\begin{tabular}{|c|c|c|c|c|c|c|c|}
\hline Project & $\begin{array}{c}\text { Efficiency } \\
\text { Score }\end{array}$ & Project & $\begin{array}{c}\text { Efficiency } \\
\text { Score }\end{array}$ & Project & $\begin{array}{c}\text { Efficiency } \\
\text { Score }\end{array}$ & Project & $\begin{array}{c}\text { Efficiency } \\
\text { Score }\end{array}$ \\
\hline $\mathbf{0 1}$ & 96.95 & 24 & 7.94 & 36 & 100 & 51 & 21.17 \\
\hline $\mathbf{0 2}$ & 35.54 & 25 & 51.69 & 37 & 5.14 & 52 & 100 \\
\hline $\mathbf{0 4}$ & 100 & 27 & 100 & 38 & 15.26 & 54 & 48.70 \\
\hline $\mathbf{0 6}$ & 100 & 28 & 95.03 & 39 & 7.40 & 55 & 3.42 \\
\hline $\mathbf{1 0}$ & 100 & 29 & 100 & 40 & 4.49 & 57 & 100 \\
\hline $\mathbf{1 4}$ & 6.27 & 30 & 47.61 & 41 & 4.74 & 58 & 13.96 \\
\hline $\mathbf{1 5}$ & 100 & 32 & 22.95 & 44 & 54.98 & 59 & 100 \\
\hline $\mathbf{1 6}$ & 1.87 & 33 & 19.90 & 45 & 23.22 & 63 & 14.56 \\
\hline $\mathbf{2 0}$ & 11.85 & 34 & 38.82 & 46 & 4.02 & & \\
\hline $\mathbf{2 1}$ & 13.02 & 35 & 100 & 47 & 21.79 & & \\
\hline
\end{tabular}

Parallel to time management efficiency calculation, Table 6 lists the main causes observed in projects with cost management efficiency scores of less than $100 \%$. This table indicates that fluctuations and escalations in the prices of material, equipment, and labour have the most impact on the cost managerial efficiency score. As the projects being studied are international road projects, changes in the US dollar exchange rate also impacted the efficiency. Underestimated and inaccurate appraisals and increases in the land acquisition price and compensation were other influential causes. 
Another point that needs more attention is that there are four common critical causes in Tables 4 and 6 . These are the increased quantity of work by additional works (20), inaccurate initial project scope (2), increases or changes in the scope of the project (52) and design changes (21). These causes strongly impact the management efficiency of both time and cost criteria.

Table 6 - Number of repetitions of causes influencing cost management efficiency in inefficient projects

\begin{tabular}{|c|c|c|c|c|c|c|c|c|c|c|c|}
\hline Code* & 37 & 47 & 53 & 62 & 52 & 20 & 21 & 42 & 2 & 10 & 61 \\
\hline 01 & $\mathrm{x}$ & & & & & & & & & & \\
\hline 02 & $\mathrm{x}$ & & & & & & $\mathrm{x}$ & $\mathrm{x}$ & & $\mathrm{x}$ & \\
\hline 14 & & $\mathrm{x}$ & & & $\mathrm{x}$ & & & & $\mathrm{x}$ & & \\
\hline 16 & $x$ & & $\mathrm{x}$ & & $\mathrm{x}$ & $\mathrm{x}$ & & & & & \\
\hline 20 & $\mathrm{x}$ & & & & & & & & & $\mathrm{x}$ & \\
\hline 21 & $\mathrm{x}$ & $\mathrm{x}$ & & & & $\mathrm{x}$ & & & & $\mathrm{x}$ & \\
\hline 24 & & & $\mathrm{x}$ & $\mathrm{x}$ & $\mathrm{x}$ & $\mathrm{x}$ & $\mathrm{x}$ & $\mathrm{x}$ & & & \\
\hline 25 & & $\mathrm{x}$ & & & & & & & $\mathrm{x}$ & & \\
\hline 28 & & & & & $\mathrm{x}$ & & $\mathrm{x}$ & $\mathrm{x}$ & & & \\
\hline 30 & $\mathrm{x}$ & & & & & & & & & & \\
\hline 32 & $\mathrm{x}$ & & & & & & & & & & \\
\hline 33 & & $\mathrm{x}$ & & & $\mathrm{x}$ & $\mathrm{x}$ & & $\mathrm{x}$ & & & \\
\hline 34 & $\mathrm{x}$ & & & & & $\mathrm{x}$ & & $\mathrm{x}$ & $\mathrm{x}$ & & \\
\hline 37 & & & $\mathrm{x}$ & $\mathrm{x}$ & & & $\mathrm{x}$ & & & & \\
\hline 38 & $\mathrm{x}$ & $\mathrm{x}$ & & & & & & & & & $\mathrm{x}$ \\
\hline 39 & $\mathrm{x}$ & $\mathrm{x}$ & $\mathrm{x}$ & $\mathrm{x}$ & & & & & & & \\
\hline 40 & $x$ & & $\mathrm{x}$ & $x$ & $\mathrm{x}$ & $\mathrm{x}$ & $\mathrm{x}$ & & & & $\mathrm{x}$ \\
\hline 41 & $\mathrm{x}$ & & & & & & & & $\mathrm{x}$ & & \\
\hline 44 & & $\mathrm{x}$ & & & & & & & & & \\
\hline 45 & $\mathrm{x}$ & $\mathrm{x}$ & & $\mathrm{x}$ & & & & & & & \\
\hline 46 & $\mathrm{x}$ & & $\mathrm{x}$ & & & & & & & $\mathrm{x}$ & \\
\hline 47 & $\mathrm{x}$ & & & & $\mathrm{x}$ & & & & & & $\mathrm{x}$ \\
\hline 51 & $\mathrm{x}$ & & & $\mathrm{x}$ & & & & & & & \\
\hline 54 & $x$ & & & $\mathrm{x}$ & & & & & & & \\
\hline 55 & $\mathrm{x}$ & $\mathrm{x}$ & $\mathrm{x}$ & $\mathrm{x}$ & & & & $\mathrm{x}$ & $\mathrm{x}$ & & \\
\hline 58 & $\mathrm{x}$ & $\mathrm{x}$ & $\mathrm{x}$ & & & & $\mathrm{x}$ & & & & \\
\hline 63 & & $\mathrm{x}$ & $\mathrm{x}$ & & & & & & & & \\
\hline Repetition & 19 & 11 & 9 & 8 & 7 & 6 & 6 & 6 & 5 & 4 & 3 \\
\hline$*$ & \multicolumn{11}{|c|}{ Refer to Appendix 1} \\
\hline
\end{tabular}


In order to investigate the significance of the aforementioned 10 cost causes on the cost management performance, and effect of previously defined 20 time causes on time management performance, sensitivity analysis tool was adopted. With the help of sensitivity analysis, authors verified the influence of every single cause on the overall efficiency of the management team assigned for projects. This specific analysis enabled the identification of the degree of deviation in other words, the magnitude of impact of each cause in terms of effect on the efficiency of project management of construction projects. The sequential steps followed in this study for identifying the magnitude of impact of each cause on management efficiency are; (1) Elimination of each cause as input from the critical causes list one by one, (2) Computation of the efficiency value of project managers subsequent to execution of step (1), (3) calculation of the rate of declines in value from previous efficiency average in order to determine the level of significance for each cause.

For each project, decrease in management efficiency score compared to original one reflects the importance of eliminated cause in that project management performance. As performed by Montoneri et al [31], amount of deviation in the new efficiency average of all projects from the original efficiency average indicates the level of significance for the eliminated cause.

Tables 7 and 8 present the results of sensitivity analysis and the change in the new efficiency average compared with the original efficiency score average for the time and cost criteria.

According to the results summarized in Table 7 , the deviations given by omitting design changes (cause 21), delay in mobilization by contractor (cause 33), and poor project management (cause 7) from the original average value are greater than for the other inputs. Thus, it can be concluded that these causes have a greater impact on the efficiency of the time management of projects. (See Appendix 1)

Table 7 - Results of sensitivity analysis and deviations in time criteria

\begin{tabular}{|c|c|c|c|c|c|c|c|}
\hline $\begin{array}{c}\text { Cause } \\
\text { Code }\end{array}$ & $\begin{array}{c}\text { New } \\
\text { Efficiency } \\
\text { Average }\end{array}$ & $\begin{array}{c}\text { Cause } \\
\text { Code }\end{array}$ & $\begin{array}{c}\text { New } \\
\text { Efficiency } \\
\text { Average }\end{array}$ & $\begin{array}{c}\text { Cause } \\
\text { Code }\end{array}$ & $\begin{array}{c}\text { New } \\
\text { Efficiency } \\
\text { Average }\end{array}$ & $\begin{array}{c}\text { Cause } \\
\text { Code }\end{array}$ & $\begin{array}{c}\text { New } \\
\text { Efficiency } \\
\text { Average }\end{array}$ \\
\hline 2 & 67.71 & 19 & 67.71 & 35 & 67.71 & 50 & 66.74 \\
\hline 7 & 52.04 & 20 & 65.75 & 36 & 67.71 & 52 & 67.71 \\
\hline 14 & 57.34 & 21 & 24.27 & 42 & 58.74 & 58 & 63.02 \\
\hline 17 & 67.54 & 31 & 67.49 & 43 & 61.35 & 63 & 63.78 \\
\hline 18 & 67.71 & 33 & 42.09 & 44 & 62.56 & 64 & 66.66 \\
\hline
\end{tabular}

As can be seen from Table 8, the studied projects are most sensitive to underestimated and inaccurate appraisals (cause 53), changes in the exchange rate (cause 47), and an increase in the quantity of work (cause 20). Based on the results, these causes have a greater impact on the cost management efficiency than other causes. 
Cost and Time Management Efficiency Assessment for Large Road Projects Using ...

Table 8 - Results of sensitivity analysis and deviations in cost criteria

\begin{tabular}{|c|c|c|c|}
\hline Cause Code & $\begin{array}{c}\text { New Efficiency } \\
\text { Average }\end{array}$ & Cause Code & $\begin{array}{c}\text { New Efficiency } \\
\text { Average }\end{array}$ \\
\hline 2 & 37.96 & 47 & 37.07 \\
\hline 20 & 37.35 & 52 & 44.77 \\
\hline 21 & 47.64 & 53 & 29.66 \\
\hline 37 & 41.63 & 61 & 42.56 \\
\hline 42 & 46.42 & 62 & 47.17 \\
\hline Average of efficiency scores in Table 5: 47.17
\end{tabular}

The results obtained by the sensitivity analysis using the Performance Improvement Management software are in line with the results in Tables 3 and 5. In the same way, these results confirm that the causes investigated here not only impact on the final cost and time of projects, but also influence the efficiency of time and cost management.

\subsection{Importance of time and cost management efficiency}

An awareness of the extent of the interaction between time and cost management efficiency is an important point. This may help decision makers and project managers to undertake countermeasures to reduce the probability of time and cost overruns. Consequently, in the last part of the current study, projects that suffered both time and cost overruns were selected.

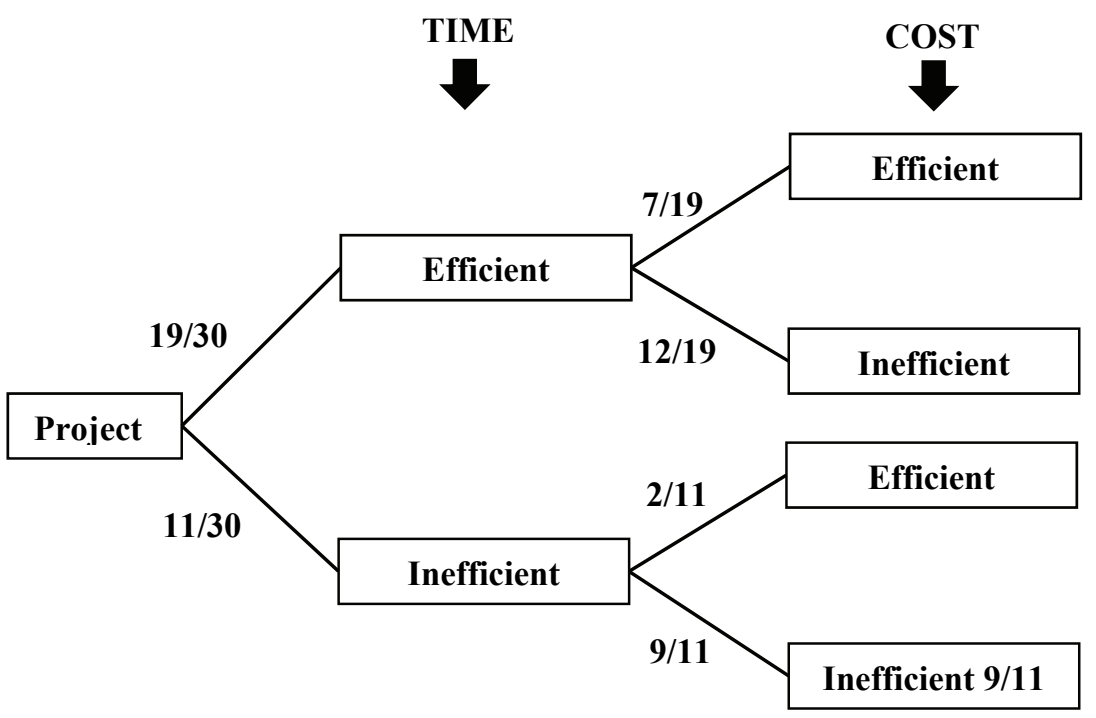

Figure 1 - Probability tree diagram of efficiency for time management criteria 


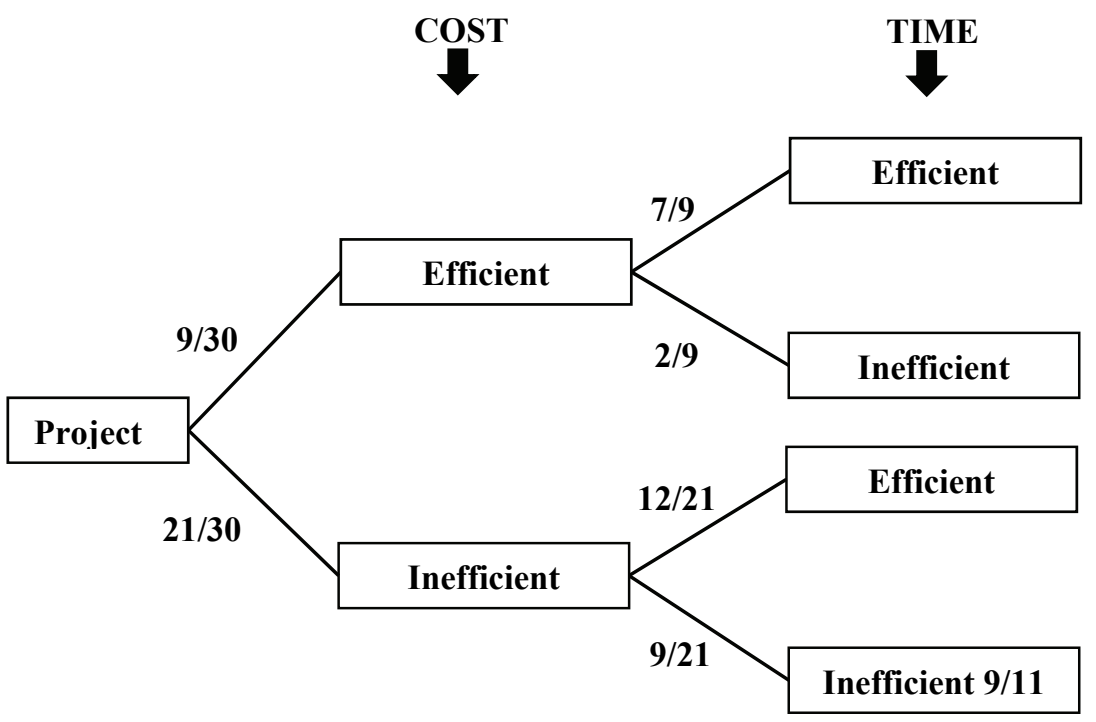

Figure 2 - Probability tree diagram of efficiency for cost management criteria

Based on Table 3 and 5, only 7 out of the total of 30 projects succeeded in managing both the time and cost criteria separately to achieve $100 \%$ efficiency. Projects 11 and 21 have inefficient management in terms of time and cost criteria, respectively. Figures 1 and 2 depict probability tree diagrams of the projects in terms of time and cost management efficiency.

Figure 1 plainly shows that, in the case of inefficient time management, the likelihood of inefficient cost management is approximately 4 times higher than that of efficient cost management. Therefore, time management is much more critical than cost management.

According to Figure 2, it can be concluded that the observed projects were mostly unsuccessful in terms of cost management efficiency. Moreover, efficient cost management is more likely to lead to efficient time management than to inefficient time management.

\subsection{Impact of Different Elements of Project Management}

It is believed that resulted cost and time overrun in the studied projects are a consequence of adverse causes that are rooted from other project management elements at the same time. Causes 3, 5, 8, 16, 24, 28, 45, 52 and 58 in Appendix 1 have direct relation with Communication Management, Contract Management, Quality Management, Procurement Management, Health and Safety Management, and Scope Management. Therefore, it can be concluded that not only time and cost management, but also existence of some other project management elements affects the time, and cost management efficiency. In other word, time and cost management efficiency is a portion of most of other project management elements combination. 


\section{CONCLUSIONS}

The purpose of this article was to fill a gap in the literature concerning time and cost management efficiency for completed large transportation projects. By applying the CCR model in Data Envelopment Analysis, the authors have measured, scored, and benchmarked the schedule and budget supervisory efficiency of the studied projects. After benchmarking the efficient and inefficient projects in terms of time and cost management, a sensitivity analysis was conducted to examine the causes impacting these efficiencies.

The results obtained in this study reveal that design changes during the execution phase, delays in mobilization by the contractor, and poor project management have a significant effect on time management efficiency. Additionally, cost management efficiency is more sensitive to underestimated and inaccurate appraisals, changes in the exchange rate, and increases in the quantity of work. This article shows that this methodology can be widely and effectively applied to evaluate the managerial efficiency of project managers or project management teams in terms of time and cost or any other criteria. Moreover, using this methodology, the most significant causes impacting a project can be recognized, and these may be used as a guide for practitioners and decision makers to take the necessary countermeasures.

Another significant finding in this study is that inefficient time management of projects increases the chance of inefficient cost management to four times that of efficient cost management. Therefore, project managers should objectively pay more attention to controlling the time of the project.

The limitation of this investigation is that, this research was conducted based on projects implemented in Asia region. Also selected projects were among Asian Development Bank road projects. Moreover total number of studied projects were constrained by the number of projects that experienced time and cost overrun. Finally, the evaluated completion reports provides information, reason, and results of the problems for time and cost overrun.

It should be noted that, the obtained conclusions in this study are restricted to the selected project's data and considered criteria for those projects only.

\section{Acknowledgements}

The authors gratefully acknowledge the Asian Development Bank for providing the data used in this research through access to publicly disclosed Project Completion Reports. The data analysis phase detailed in this research would not have been possible without obtaining the data within these reports.

\section{References}

[1] Arditi, D., Akan, G. T., and Gurdamar, S., Cost overruns in public projects, International Journal of Project Management, 3, 4, 218-24, 1985.

[2] Flyvbjerg, B., Skamris Holm, M. K., and Buhl, S. L., How common and how large are cost overruns in transport infrastructure projects?, Transport Reviews, 23, 1, 71-88, 2003. 
[3] Assaf, S. A., and Al-Hejji, S., Causes of delay in large construction projects, International Journal of Project Management, 24, 4, 349-57, 2006.

[4] Shane, J. S., Molenaar, K. R., and Schexnayder, C. Construction project cost escalation factors, Journal of Management in Engineering, 25, 4, 221-29, 2009.

[5] Ahsan, K., and Gunawan, I., Analysis of cost and schedule performance of international development projects, International Journal of Project Management, 28, 1, 68-78, 2010.

[6] Ahbab, C., and Celik, T., An investigation on delay, cost overrun, quality, and health and safety problems in construction projects, 10th International Congress on Advances in Civil Engineering, Ankara: Middle East Technical University, 2012.

[7] Cheng, Y.-M., An exploration into cost-influencing factors on construction projects, International Journal of Project Management, 32, 5, 850-860, 2014.

[8] Flyvbjerg, B., Holm, M. K. s., and Buhl, S. L., What Causes Cost Overrun in Transport Infrastructure Projects, Transport Reviews, 24, 1, 3-18, 2004.

[9] Love, P. E. D., Sing, C. P., Wang, X., Irani, Z., and Thwala, D. W., Overruns in transportation infrastructure projects, Structure and Infrastructure Engineering, 10, 2, 141-159, 2014.

[10] Shehu, Z., Endut, I. R., Akintoye, A., and Holt, G. D., Cost overrun in the Malaysian construction industry projects: A deeper insight, International Jouranl of Project Management, 32, 8, 1471-1480, 2014.

[11] Eliasson, J., and Fosgerau, M., Cost overruns and demand shortfalls - Deception or selection? Transportation Research Part B, 57, 105-113, 2013.

[12] Lock, D., Project Management, Hampshire: Gower Publishing Limited, 2007.

[13] Olsen, R. P., Can project management be defined?, Project Management Institute, 1971.

[14] Munns, A. K., and Bjeirmi, B. F., The role of project management in achieving project success, International Journal of Project Management, 14, 2, 81-87, 1996.

[15] Besner, C., and Hobbs, B., The Perceived Value and Potential Contribution of Project Management Practices to Project Success, Project Management Journal, 37, 3, 37-48, 2006.

[16] Chou, J.-S., and Yang, J.-G., Project Management Knowledge and Effects on Construction Project Outcomes An Empirical Study, Project Management Journal, 43, 5, 47-67, 2012.

[17] de Carvalho, M. M., Patah, L. A., and Bido, D. d. S., Project management and its effects on project success, Cross-country and cross-industry comparisons, International Journal of Project Management, 33, 7, 1509-1522, 2015.

[18] Joslin, R., and Müller, R., Relationships between a project management methodology and project success in different project governance contexts, International Journal of Project Management, 33, 6, 1377-1392, 2015.

[19] Thakor, A. V., and Boot, A. W., Handbook of Financial Intermediation and Banking, North Holland- Elsevier, 2008. 
[20] The Value of Project Management, PMI-Project Management Institute, 2010. 2017, Retrieved from https://www.pmi.org/-/media/pmi/documents/public/pdf/whitepapers/value-of-project-management.pdf

[21] Serrador, P., and Turner, R., The Relationship Between Project Success and Project Efficiency, Project Management Journal, 46, 1, 30-39, 2015.

[22] Iyer, K. C., and Banerjee, P. S., Measuring and benchmarking managerial efficiency of project execution schedule performance, International Journal of Project Management, 34, 2, 219-236, 2016.

[23] Markham, S., Parametric versus non-parametric, Monash University, 2016. 2017, Retrieved from http://users.monash.edu/ smarkham/resources/param.htm\#param.

[24] Mester, L. J., Applying Efficiency Measurement Techniques to Central Banks, Wharton Financial Institutions Center, Wharton University of Pennsylvania, 2003. 2017, Retrived from http://fic.wharton.upenn.edu/fic/papers/03/0325.pdf

[25] El-Mashaleh, M. S., Rababeh, S. M., and Hyari, K. H., Utilizing data envelopment analysis to benchmark safety performance of construction contractors, International Journal of Project Management, 28, 1, 61-67, 2010.

[26] Trick, M., Michael Trick's Operations Research Page, Carnegie Mellon University, 1998. Retrieved from http://mat.gsia.cmu.edu/classes/QUANT/NOTES/chap12.pdf

[27] Guidelines for the Evaluation of Public Sector Operations, Asian Development Bank, 2016. 01-08-2016, Retrieved from

http://www.adb.org/sites/default/files/institutional-document/32516/guidelines-evaluationpublic-sector.pdf.

[28] Charnes, A., Cooper, W. W., and Rhodes, E., Measuring the efficiency of decision making units, European Journal of Operational Research, 2, 6, 429-44, 1978.

[29] Banker, R. D., Charnes, A., and Cooper, W. W., Some Models for Estimating Technical and Scale Inefficiencies in Data Envelopment Analysis, Management Science, 30, 9, 1078-1092, 1984.

[30] Cooper, W. W., Seiford, L. M., and Tone, K., Data Envelopment Analysis, Springer US, 2007.

[31] Montoneri, B., Lin, T. T., Lee, C.-C., and Huang, S.-L., Application of data envelopment analysis on the indicators contributing to learning and teaching performance, Teaching and Teacher Education, 28, 3, 382-395, 2012.

[32] Daneshvar, S., Izbirak, G., and Javadi, A., Sensitivity analysis on modified variable returns to scale model in Data Envelopment Analysis using facet analysis, Computers \& Industrial Engineering, 76, 32-39, 2014.

[33] Vartanian, T. P., Secondary Data Analysis: New York, Oxford University Press, 2011.

[34] Emrouzinejad, Ali, Thanassoulis, Emmanuel, PIM-DEA, PIM-DEA soft (Data Envelopment Analysis Software), 2017. Retrieved from http://deasoftware.co.uk/

[35] Cooper, W. W., Seiford, L. M., and Tone, K., Introduction to data envelopment analysis and its uses, with DEA-solver software and references, Springer Science \& Business Media, 2006. 


\section{APPENDICES}

Appendix 1. Full List of Causes Affecting Time \& Cost Criteria and their Repetition in Studied Projects, respectively

\begin{tabular}{|c|c|c|c|}
\hline \multirow{2}{*}{$\stackrel{0}{0}$} & \multirow{2}{*}{ Affecting Cause } & \multicolumn{2}{|c|}{ \# Repetition } \\
\hline & & in Time & in Cost \\
\hline 1 & Inadequate front-end planning of project & 1 & 0 \\
\hline 2 & Inaccurate initial project scope and cost estimate & 7 & 7 \\
\hline 3 & $\begin{array}{l}\text { Inadequate communication between design and construction } \\
\text { parties }\end{array}$ & 1 & 1 \\
\hline 4 & Poor site management & 1 & 0 \\
\hline 5 & Not communicating with all parties dealing with the budget & 1 & 1 \\
\hline 6 & Owner interference in the project & 1 & 1 \\
\hline 7 & $\begin{array}{l}\text { Poor project management, construction management, and } \\
\text { supervision }\end{array}$ & 8 & 0 \\
\hline 8 & $\begin{array}{l}\text { Poor contract management (inexperience of following contract } \\
\text { condition) }\end{array}$ & 2 & 1 \\
\hline 9 & Poor provision of information to project participants & 1 & 1 \\
\hline 10 & Inflation & 2 & 4 \\
\hline 11 & $\begin{array}{l}\text { Failure to resolve change orders and prevent them from becoming } \\
\text { claims/disputes }\end{array}$ & 1 & 1 \\
\hline 12 & Too many construction activities going on at the same time & 1 & 1 \\
\hline 13 & $\begin{array}{l}\text { No financial incentive to contractor to finish the project ahead of } \\
\text { schedule }\end{array}$ & 1 & 1 \\
\hline 14 & $\begin{array}{l}\text { Slowness of the owner's decision-making process (approval of } \\
\text { activities) }\end{array}$ & 10 & 1 \\
\hline 15 & Slow financial and payment procedures adopted by the client & 4 & 2 \\
\hline 16 & $\begin{array}{l}\text { Contract modifications and variations (replacement, addition, and } \\
\text { change) }\end{array}$ & 0 & 2 \\
\hline 17 & Delay in approval of feasibility study, drawings, and material & 6 & 0 \\
\hline 18 & Financial difficulties of owner/client & 5 & 0 \\
\hline 19 & $\begin{array}{l}\text { Long period between time of bidding and contract award (initial } \\
\text { delay) }\end{array}$ & 16 & 2 \\
\hline 20 & Increase in quantity of work (additional works) & 9 & 7 \\
\hline 21 & Design changes & 10 & 10 \\
\hline 22 & Absence of consultant's staff on the project site & 1 & 0 \\
\hline
\end{tabular}




\begin{tabular}{|c|c|c|c|}
\hline 23 & $\begin{array}{l}\text { Lack of technical and managerial skills of consultant's staff (poor } \\
\text { performance) }\end{array}$ & 4 & 0 \\
\hline 24 & Lack of quality assurance, control & 1 & 1 \\
\hline 25 & $\begin{array}{l}\text { Poor documentation - incomplete drawings, poor drawings, design } \\
\text { deficiencies }\end{array}$ & 1 & 0 \\
\hline 26 & Slow inspection of completed works & 1 & 1 \\
\hline 27 & Equipment and manpower shortage and bad distribution on site & 4 & 0 \\
\hline 28 & Poor communication with consultant and owner & 1 & 0 \\
\hline 29 & Financial difficulties of contractor & 4 & 0 \\
\hline 30 & Low productivity of labour & 0 & 2 \\
\hline 31 & Inadequate contractor experience (poor performance of contractor) & 10 & 0 \\
\hline 32 & Rework and wastage of materials & 1 & 1 \\
\hline 33 & Delay in mobilization by contractor & 13 & 0 \\
\hline 34 & Inadequate and incompetent subcontractors & 0 & 1 \\
\hline 35 & Slow or delayed material or equipment delivery to project site & 7 & 2 \\
\hline 36 & $\begin{array}{l}\text { Unavailability or shortage of required materials in the local market } \\
\text { on time }\end{array}$ & 5 & 21 \\
\hline 37 & $\begin{array}{l}\text { Fluctuation and escalation in prices (materials, machinery, labour, } \\
\text { equipment) }\end{array}$ & 2 & 0 \\
\hline 38 & Monopoly of construction materials supply (steel, cement) & 1 & 1 \\
\hline 39 & Equipment availability and failure & 1 & 1 \\
\hline 40 & Lack of maintenance for the equipment & 1 & 1 \\
\hline 41 & Skilled labour shortage & 2 & 7 \\
\hline 42 & $\begin{array}{l}\text { Poor and unforeseen site conditions (location, ground, geological, } \\
\text { events, security) }\end{array}$ & 5 & 1 \\
\hline 43 & Severe weather problems (heat, cold, snow, rain, cyclone) & 12 & 1 \\
\hline 44 & Political issues, changes & 5 & 0 \\
\hline 45 & Poor health and safety conditions on site & 0 & 2 \\
\hline 46 & $\begin{array}{l}\text { Changes in laws and regulations during the project, obstacles from } \\
\text { government }\end{array}$ & 1 & 13 \\
\hline 47 & Change in exchange rate & 0 & 2 \\
\hline 48 & Inadequate design team experience & 1 & 3 \\
\hline 49 & Extension of the construction phase (delay) & 1 & 1 \\
\hline 50 & $\begin{array}{l}\text { Complicated administrative and governmental procedures } \\
\text { (institutional problems) }\end{array}$ & 6 & 3 \\
\hline
\end{tabular}




\begin{tabular}{|c|c|c|c|}
\hline 51 & Damage of structure and equipment breakdown (flood, cyclone) & 1 & 11 \\
\hline 52 & Increase or change in scope of the project & 8 & 12 \\
\hline 53 & $\begin{array}{l}\text { Underestimate and inaccurate appraisal (missing measures, cost } \\
\text { adjustment) }\end{array}$ & 2 & 2 \\
\hline 54 & Extension of consultant contract & 0 & 1 \\
\hline 55 & Court cases (litigation) & 2 & 3 \\
\hline 56 & $\begin{array}{l}\text { Unexpected issues (public obstruction, earthquake, flood, security } \\
\text { issues) }\end{array}$ & 1 & 1 \\
\hline 57 & Quitting the work by contractor & 3 & 1 \\
\hline 58 & $\begin{array}{l}\text { Poor procurement procedure (longer period or procedures in } \\
\text { bidding) }\end{array}$ & 11 & 1 \\
\hline 59 & Change in quality of the work & 1 & 1 \\
\hline 60 & Inaccurate estimation for duration of the project & 0 & 6 \\
\hline 61 & $\begin{array}{l}\text { Additional project management, consultancy, and administration } \\
\text { costs }\end{array}$ & 0 & 11 \\
\hline 62 & $\begin{array}{l}\text { Increase in the amount of land acquisition, price, and } \\
\text { compensation }\end{array}$ & 0 & 0 \\
\hline 63 & Delay in land acquisition & 8 & 0 \\
\hline 64 & Delay in appointment of consultant & 7 & 0 \\
\hline 65 & Low contract bid & 1 & 0 \\
\hline 66 & Repetition of tendering or bidding procedure & 3 & 0 \\
\hline
\end{tabular}

Appendix 2. Specifications of selected projects

\begin{tabular}{|c|c|c|c|c|c|}
\hline $\begin{array}{c}\text { Description } \\
\text { /Project }\end{array}$ & Country & $\begin{array}{c}\text { Estimated } \\
\text { Cost } \\
\$(\text { Million })\end{array}$ & $\begin{array}{c}\text { Cost } \\
\text { Overrun } \\
(\%)\end{array}$ & $\begin{array}{c}\text { Estimated } \\
\text { Duration } \\
(\text { Months })\end{array}$ & $\begin{array}{c}\text { Time } \\
\text { Overrun } \\
(\%)\end{array}$ \\
\hline 01 & Bangladesh & 15.60 & 10.71 & 624 & 92 \\
\hline 02 & New Guinea & 15.34 & 29.20 & 528 & 41 \\
\hline 03 & Pakistan & 178 & -12.07 & 648 & 48 \\
\hline 04 & Laos & 23.75 & 6.32 & 1369 & 49 \\
\hline 05 & Bangladesh & 696 & 8.29 & 1581 & 0 \\
\hline 06 & Bangladesh & 105.5 & 2.49 & 792 & 36 \\
\hline 07 & Nepal & 50 & -3 & 1613 & 7 \\
\hline 08 & Guinea & 97 & -57 & 1886 & 69 \\
\hline
\end{tabular}


Cost and Time Management Efficiency Assessment for Large Road Projects Using ...

\begin{tabular}{|c|c|c|c|c|c|}
\hline 09 & India & 308.8 & -2 & 1340 & 109 \\
\hline 10 & Tonga & 12.5 & 6.48 & 1552 & 12 \\
\hline 11 & Nepal & 16.9 & -8 & 2190 & 33 \\
\hline 12 & Thailand & 211 & -30 & 2190 & 67 \\
\hline 13 & Viet Nam & 237 & -31 & 1742 & 20 \\
\hline 14 & Laos & 44.8 & 101 & 1217 & 26 \\
\hline 15 & China & 532 & 4 & 228 & 299 \\
\hline 16 & Sri Lanka & 295.9 & 206 & 72 & 117 \\
\hline 17 & China & 795.5 & -8 & 2555 & -7 \\
\hline 18 & Laos & 50 & 21 & 60 & 80 \\
\hline 19 & China & 360 & -4 & 1490 & 49 \\
\hline 20 & Fiji & 90 & 88 & 2283 & 148 \\
\hline 21 & Sri Lanka & 123.3 & 48 & 1825 & 40 \\
\hline 22 & Cambodia & 88.1 & -1 & 40 & 65 \\
\hline 23 & China & 345 & -3.41 & 1798 & 40 \\
\hline 24 & China & 770.3 & 28 & 1796 & 46 \\
\hline 25 & Cambodia & 77.5 & 12 & 1200 & 58 \\
\hline 26 & Laos & 37.5 & -27 & 1551 & 47 \\
\hline 27 & Laos & 39.2 & 26 & 96 & -6 \\
\hline 28 & China & 757 & 28 & 48 & 0 \\
\hline 29 & Sri Lanka & 92.5 & 10 & 1824 & 15 \\
\hline 30 & India & 378 & 21.80 & 1440 & 179 \\
\hline 31 & Pakistan & 236 & -17 & 2190 & 33 \\
\hline 32 & India & 92 & 45 & 2371 & 62 \\
\hline 33 & China & 582 & 32 & 1490 & 33 \\
\hline 34 & Bhutan & 34.10 & 6 & 1825 & 35 \\
\hline 35 & Tajikistan & 26.8 & 3 & 1460 & 29 \\
\hline 36 & China & 455.2 & 2 & 1492 & 37 \\
\hline 37 & China & 762 & 75 & 1643 & 50 \\
\hline 38 & China & 611.8 & 41 & 1875 & 60 \\
\hline 39 & China & 882 & 52 & 2010 & 36 \\
\hline 40 & China & 2077 & 49 & 2190 & 0 \\
\hline 41 & India & 649 & 53 & 1440 & 114 \\
\hline
\end{tabular}




\begin{tabular}{|c|c|c|c|c|c|}
\hline 42 & China & 834 & -3 & 1826 & 40 \\
\hline 43 & Tajikistan & 23.6 & -1 & 1216 & 28 \\
\hline 44 & China & 726 & 11 & 1339 & 25 \\
\hline 45 & China & 778.1 & 27 & 1825 & -13 \\
\hline 46 & Mongolia & 78.14 & 96 & 1642.5 & 122 \\
\hline 47 & Azerbaijan & 93.2 & 47.64 & 1094 & 17 \\
\hline 48 & India & 285.7 & -1 & 1825 & 58 \\
\hline 49 & Pakistan & 423.6 & -29 & 1095 & 33 \\
\hline 50 & Kyrgyz & 43.4 & 0 & 1065 & 18 \\
\hline 51 & China & 745 & 49.03 & 1826 & 20 \\
\hline 52 & Afghanistan & 80 & 3.11 & 940 & 114 \\
\hline 53 & India & 400 & -3.25 & 1186 & 54 \\
\hline 54 & China & 1425 & 21.31 & 1642.5 & 0 \\
\hline 55 & China & 519.51 & 73 & 2281 & 8 \\
\hline 56 & Tajikistan & 64.5 & -7.09 & 2100 & 13 \\
\hline 57 & China & 524.55 & 2.60 & 1398 & 0 \\
\hline 58 & China & 1566 & 27.60 & 1825 & 15 \\
\hline 59 & Afghanistan & 140.9 & 24.41 & 1260 & 62 \\
\hline 60 & China & 594 & -4.97 & 1855 & 20 \\
\hline 61 & Kyrgyz & 30.3 & -30 & 1002 & 55 \\
\hline 62 & Kyrgyz & 76.5 & -7 & 2191 & 4 \\
\hline 63 & Honduras & 64.6 & 26.47 & 1525 & 46 \\
\hline
\end{tabular}


